\title{
Sulapa Eppa As The Basic or Fundamental Philosophy of Traditional Architecture Buginese
}

\author{
Syarif ${ }^{1, *}$, Ananta Yudono ${ }^{2}$, Afifah Harisah $^{1}$, and Moh Mochsen Sir $^{1}$ \\ ${ }^{1}$ The Architecture Department Faculty of Engineering Unhas, Makassar, Indonesia \\ ${ }^{2}$ PWK Department Faculty of Engineering Unhas, Makassar, Indonesia
}

\begin{abstract}
In general, traditional buildings in South Sulawesi Province are built based on the hopes for better future. Therefore, the house is considered as the manifestation of the natural universe (macrocosms). House and settlements are ones of the highest cultural heritage works, in Buginese communities. The value of sacredness and robustness raises the meaning of sulapa eppa philosophy, which is considered as the philosophy to realize Buginese traditional house. The purpose of this study is to discover the philosophy of sulapa eppa that underlines the formation of Buginese traditional architecture. The elements of the house present a philosophical meaning. Panrita bola serves as the informants of sulapa eppa philosophy. This research is qualitative, descriptive and explorative methods as well as naturalistic paradigm approach. The population is traditional Buginese buildings, and the samples arepost habitation, or temporarily built Buginese traditional buildings. The sampling techniques are sampling proposed and sampling incidentally. Research location is in Soppeng regency, South Sulawesi Province. The results of this study are sulapa eppa as the basic of Buginese formation traditional architecture, either physical or nonphysical. Physically, the formations of architecture are in the form, size of proportion, and building elements. And non-physically, it also can be obtained from Panrita bola, and Lontara Bugis manuscripts.
\end{abstract}

Keywords: Philosophy, sulapa eppa, Buginese traditional architecture

\section{Introduction}

Forms and models of traditional buildings that are still preserved in Indonesia, in general have strong characteristics of culture and customs that are inherited from their ancestors. Not only they have the forms and models as mentioned previously, traditional buildings also have adaptive brand on their surrounding environment; for example, using building materials taking from the nature, or forest that they protect. processing and production manners of the materials are based on the spiritual elements or norms, ancestor religions, tradition as well as local geographic conditions.

Traditional architecture can be categorized as tangible cultural work; as manifestation of honesty and sincere statement, having ability to express past cultural impressions. Architecture means culturing because traditional architecture grows and develops based on ancestor heritage from concerned nation. Existence of traditional house is a product of an evolution process, based on human past empirical experiences expressed its interaction with the nature. So, it is considered as manifestation of traditional community mind set and lifestyle in the past; definitely containing knowledge about wisdom in the interaction with natural environment. At least, it is intellectual description about the initial time of a culture and its architecture (Shima, 2006).

Architecture culture is formed by a trust at ancient mythology expressing that traditional community concept, spiritual aspect, symbols and values provide significant effects on building forms and motives. This is always taken as the basic for every life in which they live.

The significant cultural effects on traditional society will also influence on environmental pattern, house spatial pattern and its civilization.

Village pattern by Buginese in the past was grouping in dense and spreading manners. Dense grouping pattern could be mainly found at lowland, which its location was close to paddy field areas or sea side or lake. Meanwhile, the spreading pattern could be easily found at mountainous areas or plantation areas. So, manifestation of the village in the past was mainly related to their place of works so that it could be called as pallaon ruma (farmer village) and pakkaja (fishermen village or fish catcher village). In general, a house can face to one of the wind directions (may face to the West, East, South or North). This is related to Buginese cosmologist view assessing this world as a rectangular. Therefore, these four wind directions have the same position (Mardanas, 1986). 
Buginese life view on their house can be seen from their cultural behaviour and pattern; in a period of time, human was so close to their natural environment, so that their culture is cosmos manifestation (cosmography). In this issue, human living in this world considers himself as a part of the universe (macro cosmos); human life in the level of macro cosmos must 'obey' to macro cosmos control and rules. Thus, human will always try to make harmonious interaction with their nature so that they can obtain better, saver and peace life (Saing, 2010).

In Buginese traditional belief, house is considered as the natural manifestation as the center of human life cycle. It is as a place for human to be born, brought up, got married, and died. Therefore, it is considered to be sacred and greatly respected. So, it can provide peace, health, safety, welfare, and respect for its dwellers (Shima, 2006). Therefore, an existence of a house (settlement) for Buginese society is unseparated part with itself; then it is very important for home presence or ownership because the house form and manifestation symbols will be manifested on its dwellers.

Based on the discussion results above, it shows that the existence of house (settlement) of Buginese society cannot be separated from philosophical elements ranging from selection of material types to be used; implementation of field work is by panre bola (carpenter of Bugis stage house), mappatettong bola (establishing the stage house), until new menre bola (climbing new house) and maccera bola (house anniversary party). All of these events are based on the philosophical elements of sulapa eppa (perfect, pleasure, health, welfare and safety elements).

Looking at Bugis society house (settlement), with stage architecture and wooden construction are called as knock down system; so that it creates an assumption that behind the strength and sturdy are based on intangible rules or advices. This is considered as philosophical basic by panrita bola/sanro bola (Bugis traditional house architects), in implementing its tasks as an architect (Bugis traditional architect).

Then, the problem is how the philosophy of sulapa eppa as the basic of Bugis traditional architect study is and how its application on wooden stage buildings that are inhabited and owned by Bugis tribe society is.

This research aims to find out philosophical elements that have been longer as study basic of Bugis traditional architecture formation. This philosophy ability is understood and mastered by panrita bola/sanro bola (Bugis traditional building architecture).

\section{Study Review}

\section{Bugis Language and Literature}

Bugis literature written in lontara script has been started in the $16^{\text {th }}$ century, in general by people of Southeast Sulawesi. The lontara' scripts as well as Bugis literature works (classic) have close relation to life problems manifested in panngaderreng (form of Bugis culture). There is such a belief taken by Buginese that creation of script and literature were taken from one philosophical background of panngaderreng as one unity (Mattulada, 1993).

So, at the beginning, Buginese literatures were written on leaves of lontar/siwalan (Borassus sp.); results of these writing collections were then called as lontara'. The Lontara' presents sacred literature, in the forms of mythologist beliefs and spells. Then, there was also a development of literature works having characteristics of world life, this was based on the development of lontara' and society life behavior as well as its culture.

Related to the creation of sound signs called as lontara' script, there is an assumption that this was derived from Bugis people mythologist belief and view, considering this universe as sulapa' eppa' wolasuji (rhombus). Definition of wolasuji/walasuji is a partititor having function as an accessories in tribal ceremony or Bugis wedding party; it is made of bamboo skin woven diagonally forming a shape of rhombus (figure 1).

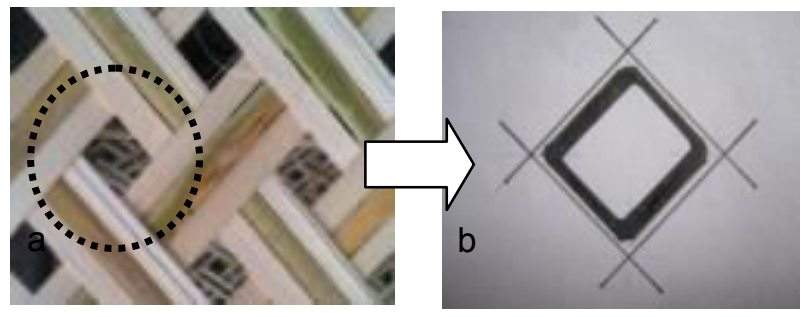

Fig. 1. Production Process of Letter "sa”, (a) wolasuji (woven bamboo), (b) letter "sa".

Figure 1 shows the production process of letter "sa" (Bugis lontara script), taking the motif from "wolasuji" (woven bamboo that is made specifically for tribal ceremony). Motif of letter "sa" (shape of rhombus) is the pioneer philosophy of sulapa eppa, with its four angles shine scared spiritual values.
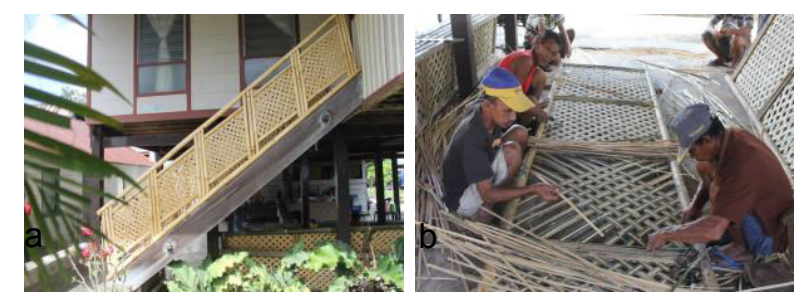

Fig. 2. application of wolasuji, (a)wolasuji (ladder fence), (b) production process of wolasuji..

Figure 2 shows application of wolasuji as "railing" or fence, in the ladder of Bugis stage house. It indicates that the house dwellers have had party.

Philosophy of sulapa eppa is also manifested in human, often called as "sulapa eppa na taue" (philosophy of human rectangular), this is in line with an opinion by Pelras (2005) stating that portrait of Bugis people mentality is dominated by four characteristics. In the lontara', it is mentioned four characteristics namely sulapa' eppa' (rectangular) that should be owned by each good leader (figure 3 ). A prospective one to be a good leader should not only be taken from proper 
descendant, he or she should also be warani (brave), macca (intellect), sugi (rice), and panrita (kind).

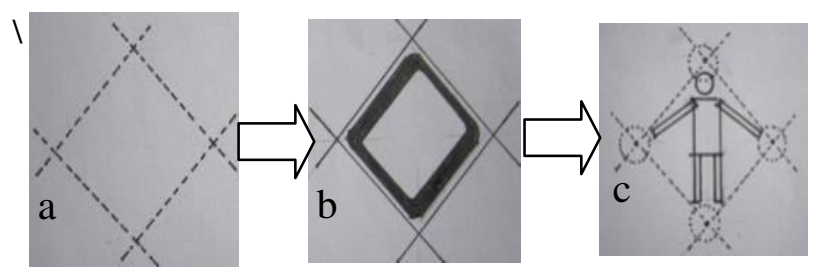

Fig. 3. Creation Process of Sulapa Eppa'na Taue (human rectangular) (a)Schematic of letter "sa", (b) script letter of lontara "sa”" (c) Sulapa eppa'na taue.

It can also be seen totality in daily expression indicating that a man can be perfect or have sulapa' eppa', if he can bind his spouse in a marriage, and in Bugis belief that 'only if you are assigned to be a leader, then you must have sulapa' eppa'.

\section{Balance of Four Side Areas}

According to Pelras (2005), in-depth diachronic study about mythology and literature creates patterns of ethos and beliefs formed in early South Sulawesi society. This can be seen from symbolic images of cloth motifs having strong links with the concepts of real and abstract spaces in Bugis society. The order in Bugis society is shown through the philosophy of sulapa 'eppa', which literally means "four sides", a four-sided world view showing totality.

According to Morrell (2005) that similar philosophy can also be found in many Austronesian societies, and in South Sulawesi, historical manuscripts indicates that this philosophy structures various types of beliefs and practices both in spiritual and material forms, in terms of cosmology, politics, and social life. Furthermore, there are four classifications of the natural environment elements, human life and efforts, for example division of world base into wind, water, fire and soil, leading to totality concept giving mutual correlation which its significance can still survive in contemporary communities (Robinson, 2005).

Throughout the world, the four sides governing the universe, usually following the four wind directions, and often shining from the center of spiritual, can commonly be found in ancient societies, although the universal nature of the concept is modified based on different interpretations, adopted based on specific worldview (Abidin , 1969).

According to Mattulada (1993) that there is an ancient saying that supposedly derived from Arung Palakka proposing a question about the four elements that actually are required as a condition for him to be sworn in as king. The saying goes: "do not count on these four things, namely: courage, proficiency, descent, wealth. Because all of which are corrupted wood; unsuitable in three places; put on the ground, these will be surrounded by powder; soaked in the water, these will be quickly infused by water; put in a charred, the fire will be soon got lost; soaked in the water, these will be quickly infused by water.

\section{Concept of Cosmos Shape}

According to Bugis assumption, this universe is in the shape of "rectangular". The concept of a rectangular is so dominant that it influences on the lives of Bugis, so it is their philosophy and life view so called as sulapa eppa (four sides), and has the principle of life balance measurement. The philosophy of sulapa eppa shows that the Bugis view of life indicates the effort for self-perfect that has been taught by hereditary in an oral manner (Saing, 2010, Abidin 1969).

Based on the source of lontara (Bugis manuscripts), one related to the philosophy of sulapa eppa states village, appabolang yard (plot) and building plan of Bugis stage house; then, all of which will be considered perfect if these are rectangular. So, all of the floor plans and home yards of Bugis stage houses have always pattern of rectangular shape.

In accordance with the philosophy of sulapa eppa, so in the past, Buginese, would be called to be perfect if they meet four kinds of natures, namely; wind, fire, water and soil (table 1).

Table 1. Meanings of Sulapa Eppa Elements.

\begin{tabular}{|c|c|c|}
\hline $\begin{array}{c}\text { Sulapa Eppa } \\
\text { Elements }\end{array}$ & Colors & $\begin{array}{l}\text { Meanings } \\
\text { (symbols) }\end{array}$ \\
\hline Wind & Yellow & Greatness \\
\hline Fire & Red & Courage \\
\hline Water & White & Holiness \\
\hline Land & Black & Magical power \\
\hline
\end{tabular}

Based on table 1 above, the wind is personified as a yellow color that symbolizes "greatness", fire is the personification of red that symbolizes "courage", while water is the personification of water that symbolizes "holiness", and black is the personification of land that symbolizes darkness and is considered to have 'magical power' (figure 4). The properties that are personified through certain colors also reflect certain meanings as well. This plays an important role in the life of Buginese, as in certain ceremonies, there are the uses of white, yellow royal umbrellas; great color symbolizes the kingdom of heaven as the origin of Batara Guru that goes down to earth, then breed as the earth dweller (Saing, 2010).

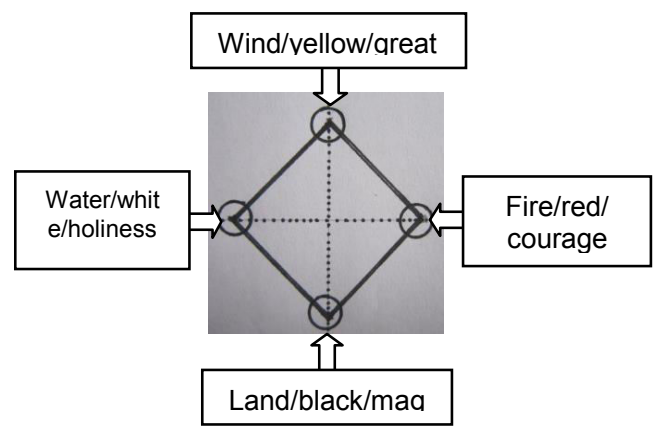

Fig. 4. Personification of sulapa eppa' (philosophy of perfectness).

The personification of the sulapa eppa colors above can also manifested from the unique way of serving food 
by Buginese, for example songkolo (steamed glutinous rice), usually intentionally colored based on its assignment. Yellow Songkolo is presented for "master of wind", red songkolo is presented for "master of fire, white songkolo is presented for "master of water", and black songkolo is presented for "master of land" (Pelras, 2005).

Table 2. Offerings of Sulapa Eppa Elements.

\begin{tabular}{|l|l|}
\hline \multicolumn{1}{|c|}{ Foods (songkolo) } & \multicolumn{1}{c|}{ Offerings } \\
\hline Yellow & Master of wind \\
\hline Red & Master of fire \\
\hline White & Master of water \\
\hline Black & Master of land \\
\hline
\end{tabular}

In table 2 above, the colors of food are also inspired from philosophy of sulapa eppa, symbols of the songkolo food colors have long been used as part of tribal ceremony procession in Buginese society, and still can be found nowadays.

\section{Stage House as Reflection of Human Manifestation}

The house built by the Bugis tribe aims to fulfill their needs, both spiritual and pragmatic, so the establishment of the house is constantly inspired by the values of life, in the forms of character and trends, desires and ideals. The house speaks out human being, it is symbolizes all humans, beauty and greatness of its owner. House is a reflection of a dignified human language (Saing, 2010).

The symbol of the human manifestation (rupa-tau), is reflected in the shapes and structures of the house, namely the pole / foot of the house (aje-ball) as the poles, the body of the house (ale-ball) is the living space, while the head of the house (ulu-bola) is the roof (figure 5 ), and the center of the house (posi-bola) is the mast navel of the house. The dimensions of the house (height, length and width of the house) are based on the size of the body parts of the house owners (husband and wife). As the height of the house column is equal to the height of the husband plus the length of the cubit (cycles), the height of the house wall is equal to the height of the wife plus the length of the cubit. The length of the house multiples of the length of the fathom (reppa) of the husband, the width of the house is a multiple of fathom (reppa) of the wife. Thus, the proportion of the shape of the house is the reflection of the physical sizes (dimensions) of the husband-wife as the owner of the house (Shima, 2006).

The manifestation of the human symbol on Bugis stage house form vertically illustrates that there is greatly important relationships between people and their homes. Their home is not just a residential building but also a reflection of their own identity. In terms of macrocosm and human form, Bugis ancestors combined in form; size, proportion, and structure of their own homes. So that, it can be personified interrelationship between human forms, home forms and macrocosm shapes into a single, binding and integrated trinity. This trinity manifestation is closely related to the philosophy of sulapa eppa, which has long been used as the architectural principle for the Bugis community. The philosophy of sulapa eppa in Bugis society can be a reference in various fields; such as leadership, social culture, community, housing, settlement and so forth.

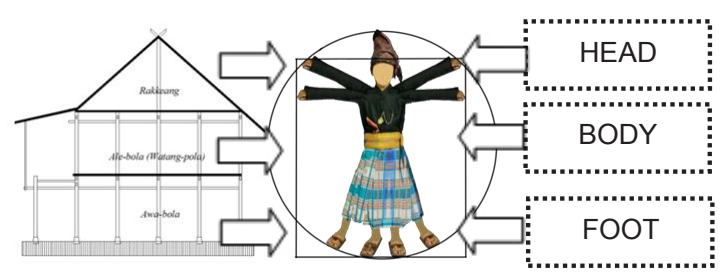

Fig. 5. House as the reflection of human manifestation (foot, body, head).

Source: Adaptation by Shima, 2006.

In figure 5, it shows reflection of human manifestation on their houses, as if the houses establish so strong as a human (dweller).

Trinity relation of macrocosms to microcosms and house dweller presents meaning and hope that the house and its dwellers will create harmonious relation with their environment and prevented from any natural disasters, such as earthquake, flood, and tornado. The expectation of dwellers on their house have been realized since the very beginning, started from the implementation of construction, until climbing on the new house); the expectations are delivered by panrita bola/sanro bola through any manners and rules that have been applied, in the building in concerned. The advices by panrita bola/sanro bola in general are the intangible ones, having philosophy of sulapa appa' aspects.

\section{Research Methodology}

This research is done by qualitative, descriptive, as well as holistic manners (complete, cannot be separated), so the qualitative researcher will not determine the research only based on the research variables, but on the whole social situations under the study including the place, actor and activity aspects that interact synergistically (Sugiyono, 2014). The "folklore" analysis method is part of collective culture, which is spread and passed down from one generation to another generation, collectively, traditionally in different versions, both in oral and exemplary forms that are completed with gestures or reminders. Part of a culture called as the folklore can be in the forms of people architecture, arts, folk painting, folk music and so forth (Bungin, 2011). The population in this study are traditional Bugis houses, and the samples are new or built houses (place). While, the informants are Panrita Bola / architect (actor), and Panre Bola / carpenter (activity). 


\section{Results and Discussion}

\section{Research Location}

The research location is focused on Bugis community concentration in Southeast Sulawesi Province, namely Soppeng Regency (figure 6). Bugis tribe is quite dominant inhibiting Soppeng Regency, stage houses have been their settlement option.

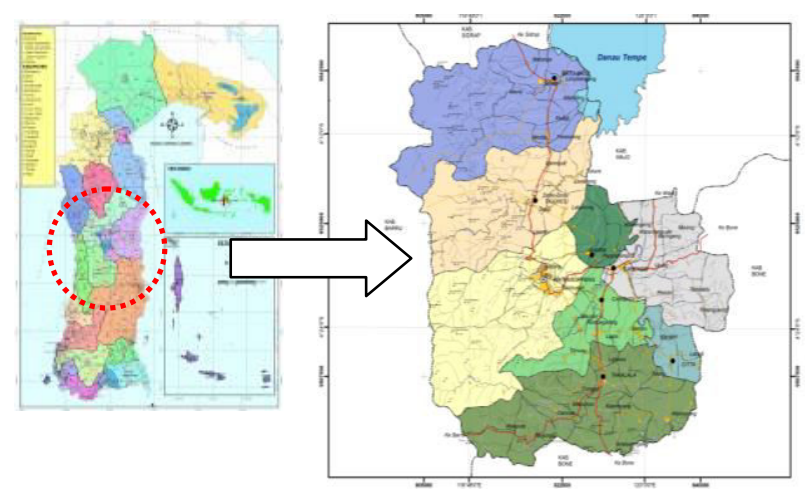

Fig. 6. Map of Soppeng Regency.

Source: Spatial Office Soppeng Regency, 2017.

Based on BPS Soppeng 2016, around 80\% (table 3) of Soppeng community inhabits or has wooden stage houses, distributed until to the village. And all of the districts in Soppeng regency can be reached by motorcycles.

Table 3.Types of Settlement and its Materials.

\begin{tabular}{|l|l|c|}
\hline No & Types of settlements /materials & Percentage \\
\hline 1 & Wooden stage house & $80 \%$ \\
\hline 2 & Roofing & $97,08 \%$ \\
\hline 3 & Wooden wall & $83 \%$ \\
\hline 4 & Bamboo wall & $4 \%$ \\
\hline 5 & Board floor & $80 \%$ \\
\hline 6 & Bamboo floor & $3,83 \%$ \\
\hline
\end{tabular}

Source: BPS, 2017.

\section{Philosophy of Sulapa Eppa in Bugis Traditional House}

\section{Selection of Plot (Appabolang)}

Selection of plot or appabolang in Bugis Tribe is always presented in a rectangular-shaped field (geometric pattern). There is a concrete shape between the shape of the plan and the shape of the plot, the layout position will be "placed" on the ground in such a way that it forms a positive space outside the layout of the floor plan. There are no negative spaces because the floor plan is always positioned in the center of the plot.

This happens because the water running from the roof is expected to always fall on their own land, and it is strongly prohibited that the water running from the roof fall on any neighboring lands. This condition results in building coverage (BC) by 30: 70 (30\% of built area and $70 \%$ of yard area), the yard is wider so there are enough rooms to grow fruit and vegetables.

The form of square plot is the most preferred shape, with the shortest side is parallel to the roadside in front of it (figure 7). The rectangular land can be philosophized as sulapa eppa, which its elements (wind, water, fire and earth) present the values of life for mankind.

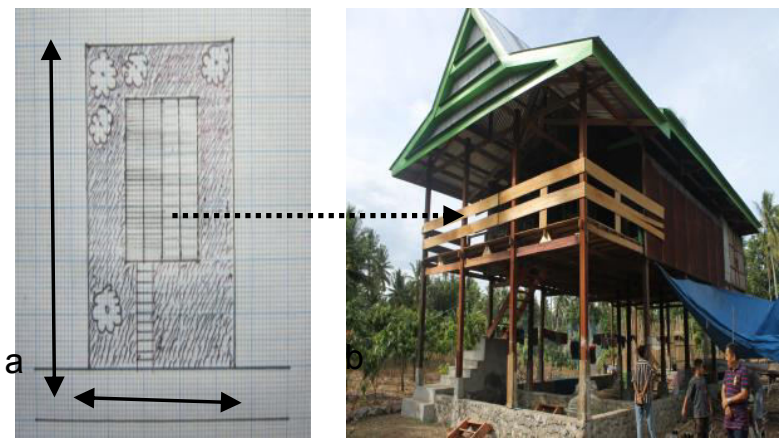

Fig. 7. Bugis Traditional house plot (a) Rectangular shape land , (b) Bugis traditional house.

\section{Plan Shape Pattern}

Bugis traditional building plan has always rectangular pattern, namely with wide side and long side. The plan is formed by row of poles (aliri) in longitudes and transversely connected to each other by pegs (pattolo) between a pole and other pole (figure 8).

The layout of the rectangular embodies the philosophy of sulapa eppa, with its elements (wind, water, fire and earth) presenting the values of life for its inhabitants.

As a form of perfection of a new settlement, at the time of climbing on a new house, it is required that every corner of the house is "diazani" simultaneously by four people, at sunset.

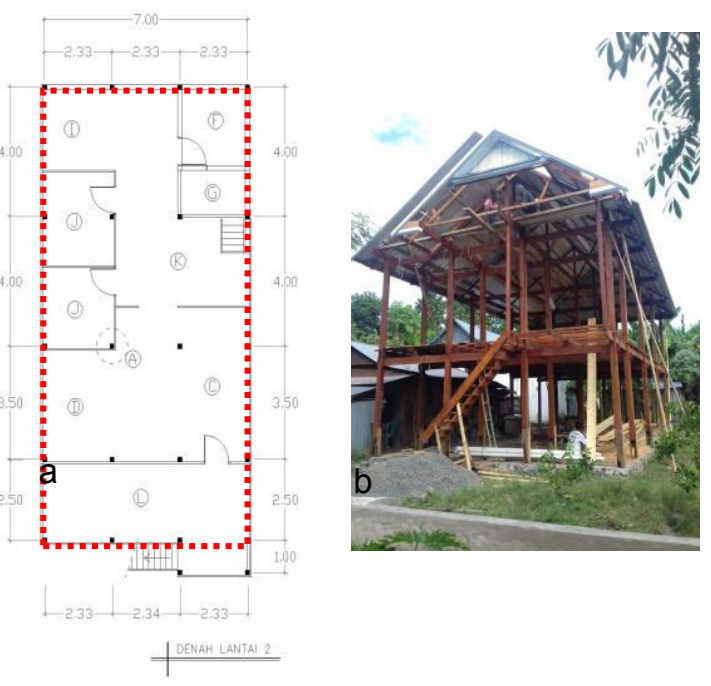

Fig. 8. Bugis Traditional House Plan (a) Rectangular Shape Plan ,(b) Bugis Traditional House. 


\section{Structural Shape}

The structure and construction of Bugis traditional buildings are arranged to form a construction with knock down system. According to Pelras (2006) stating that the form of Bugis stage building construction presents a series of structures in the form of letter " $\mathrm{H}$ " (figure 9). The series of the pole (aliri) and the flat peg (pattolo) form a solid stiffness and is the place of load force distribution to the foundation. These structural spaces can manifest the shapes of rectangular, which present the values of sulapa eppa philosophy.
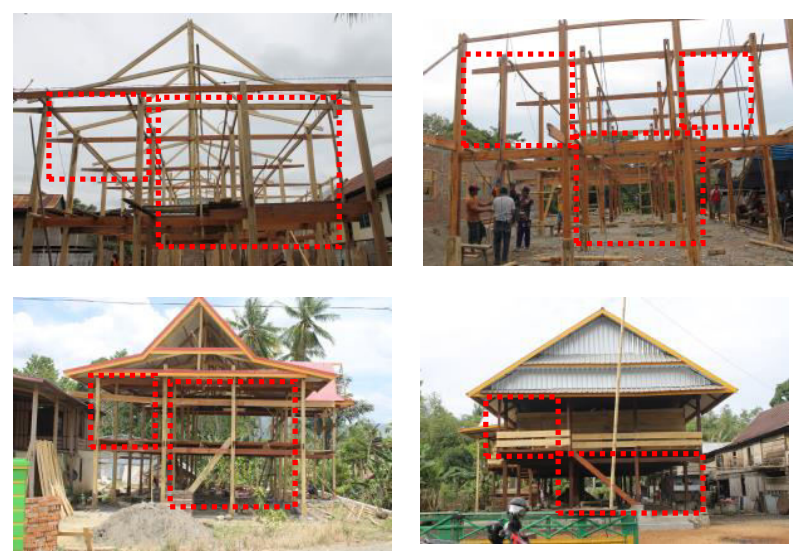

Fig. 9. Series of Rectangular Construction (sulapa eppa).

Figure 9 shows rectangular patterns that always dominate the structure and construction of Bugis traditional buildings. The phyilosophy of sulapa eppa is the principle of Bugis society.

\section{Spatial Shape Pattern}

The spatial patterns that can be found in traditional Bugis buildings generally do not have any chambers but it uses the term of room divider or "pallawa tengnga". The Pallawa tengnga is a divider space, between the front room and the living room, and between the living room and the back room. It is made of thick fabrics with dark color, and flexible because at any time, it can be dismantled or moved, if there is a ceremony or wedding ceremony.

The pattern of spatial shape is always rectangular, following the pole column module position (aliri) (figure 10).

Modular-shape space is based on the rows of poles that are transverse and longitudinal. There are three divisions of space abstract functions namely; the front space serves as guest living / room for taking a rest; the medium part is for family room, and the back room serves as girls room and kitchen / dining room.

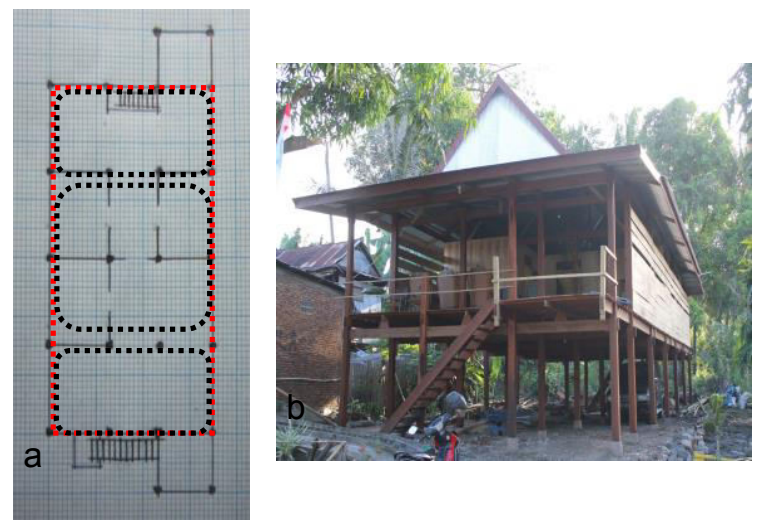

Fig 10. Bugis Traditional house rooms (a) rectangular shape rooms ,(b) Bugis Traditional house.

\section{Material Dimension Shape}

The profile shapes (dimensions) of the Bugis traditional building materials are always rectangular and square. The shape of the material dimension is determined by the function or its loads. For the vertical load distribution, the material dimension is square (pole), while for horizontal load distribution, the material dimension is rectangular (figure 11).
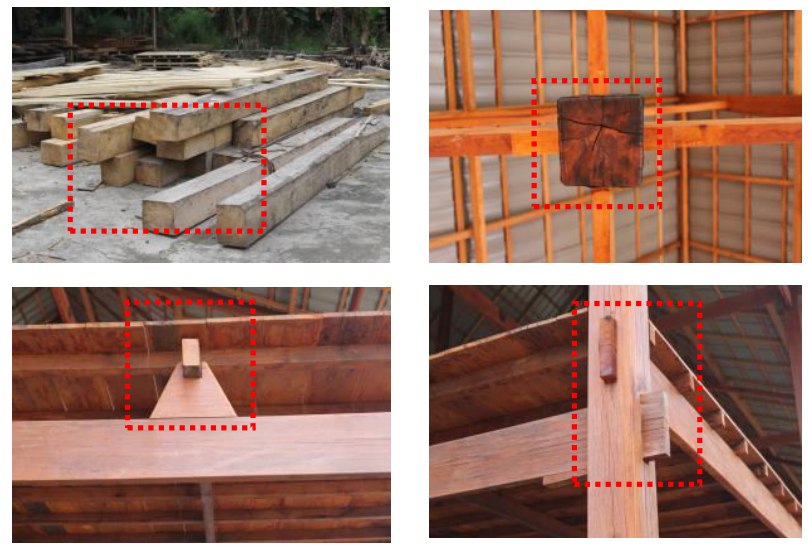

Fig. 11. Material dimension shape.

Figure 11 shows dimensions of material profile having rectangular and square shapes (philosophy of sulapa eppa).

\section{Pattern of Door and Window Elements}

The pattern of door and window elements in traditional Bugis buildings is always in rectangular shape following the philosophy of sulapa eppa; which contains the meaning of "perfectness" and "life" (figure 12). Windows and doors serve as holes for light and air going into the room. 


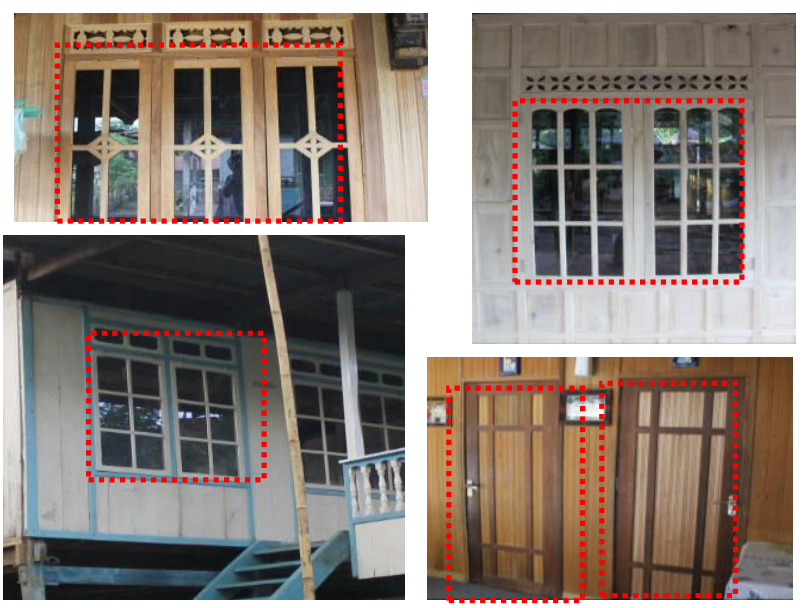

Fig. 12. Pattern of Door and Window Elements.

\section{Conclusion}

The philosophy of sulapa eppa is a sacred "term of reference" (TOR) for Bugis community, so that this philosophy can manifest itself as a basic or fundamental in Bugis traditional architecture.

The philosophy of sulapa eppa is used as the basis for determination of selecting plot (land), pattern of the floor plan, structural shape, sphere pattern, material dimension, and shape of window / door; which aims to achieve the perfection of life.

The philosophy of sulapa eppa is also used as the guidance in the field of leadership (government), social, socio-cultural, welfare and prosperity, housing and settlement, life values and self-perfectness.

\section{References}

Abidin, Mr. A. Zainal. (1969). Falsafah Hidup Sulapa Appaka Orang-orang Bugis-Makassar (Pandangan Hidup Segi Empat). Bingkisan Budaya Sulawesi Selatan Nomor 12 tahun II, Agustus Ujung Pandang : Yayasan Kebudayaan Sulawesi Selatan dan Tenggara.

Adimihardja, Kusnaka dan Parnama Salura, (2004) Arsitektur dalam Bingkai Kebudayaan. Jakarta : Architecture and Communication.

Bungin, Burhan. (2011). Metodologi Penelitian Kualitatif Aktualisasi Metodologis ke Arah Ragam Varian Kontemporer. Jakarta : PT. Raja Grafindo Persada.

Dian, Mas. (1999). Pengamatan terhadap Arsitektur Tradisional di Asia. Simposium Nasional Naskah Arsitektur Nusantara : Jelajah Penalaran Reflektif Arsitektural. Surabaya : ITS.

Hamid, Abu. (1978). Bingkisan Budaya Sulawesi Selatan.Ujung Pandang : Yaysan Kebudayaan Sulawesi Selatan.

Hamzah, Ny.Aminah P dkk.(1984). Monografi Kebudayaan Bugis di Sulawesi Selatan. Ujung Pandang : Kanwil P dan K Provensi Sulawesi Selatan.
Mardanas, Izarwisma. (1986). Arsitektur Tradisional Daerah Sulawesi Selatan. Ujung Pandang : Proyek Inventarisasi dan Dokumentasi Kebudayaan Daerah Sulawesi Selatan.

Mattulada. (1995).Latoa satu lukisan analitis terhadap antropologi politik orang Bugis. Ujung Pandang : HasanudinUniversity Press.

Morrell, Elizabeth. (2005).Simbolisme, Ruang, dan Tatanan Sosial (Tapak-tapak Waktu Kebudayaan, Sejarah, dan Kehidupan Sosial di Sulawesi Selatan, penyunting Kathryn Robinson dan Mukhlis Paeni). Makassar : Ininnawa.

Moleong, Lexy J.(2000). Metodologi Peneltian Kualitatif. Bandung : PT. Remaja Rosdakarya.

Pelras, Christian.Manusia Bugis. (2005). Jakarta : Nalar bekerja sama dengan Forum Jakarta-Paris.

Robinson, Kathryn. (1993). The Platform house : Expressions of a regional identity in the modern Indonesian nation. In Virginia Matheson Hooker (ed) Culture and Society in New Order Indonesia. Kuala Lumpur : Oxford University Press.

Robinson, Kathryn. (2005) Tradisi Membangun Rumah di Sulawesi Selatan (Tapak-tapak Waktu Kebudayaan, Sejarat, dan Kehidupan Sosial di Sulawesi Selatan. Makassar : Ininnawa.

Saing, Ama, (2010). Arsitektur Tradisional Rumah Adat Bugis-Makassar (suatu tinjauan arkeologis). Makassar : Indhira Art.

Shima, Nadji Palemmui, (2006). Arsitektur Rumah Tradisional Bugis.Makassar : Badan Penerbit UMN.

Sugiyono. (2014). Metode Penelitian Kuantitatif Kualitatif dan $R$ \& D. Bandung : Alfabeta.

Waterson, Roxana. (1993).Houses and the Built Environment in Island South-East Asia : Tracing some shared themes in the in the uses of space. 